\title{
ROLE OF THE NERVOUS SYSTEM IN THE APPEARANCE OF THE EAR ACUPUNCTURE POINTS IN THE DOG
}

\author{
J. STILL \\ Department of Diagnosis, Therapy and Control of Animal Diseases, University of Veterinary \\ Science, 61242 Brno
}

Received June 7, 1984

\begin{abstract}
Still J.: Role of the Nervous System in the Appearance of the Ear Acupuncture Points in the Dog. Acta vet. Brno, 55, 1986: 55-64.

The aim of this work was to verify the participation of the nervous system in the origin and manifestation of active ear points on a model experimental situation.

In six dogs ( 5 of the Beagle breed and 1 cross-bred, 3 males and 3 females) three experiments have been carried out: 1 . The fore paw was blocked by procaine and then strongly compressed. 2. Ganglion cervicothoracicum, sympathetically innervating the thoracic limb, head and ear auricle of the same site was blocked by procaine and then the corresponding paw was strongly compressed. 3. Nonspecific application of procaine (the dose being the same as in previous experiments) was carried out non-specifically into the subcutaneous part of the chest wall. After a certain time period, same as in previous experiments, the paw was strongly compressed. The paw compression, using an elastic bandage, lasted for 30 minutes, alternatively on both fore limbs. The electrical and algetic changes on both ear auricles were followed prior to, during and shortly after the compression.

No painful points on ear auricles were observed in the first and second experiments, the decrease of skin impedance in the expected point corresponding with the fore paw being sporadically observed. This statistically highly significant difference $(\mathbf{P}<0.01)$ when compared with the cited similar experiment without specificic effect of the local anesthetic corroborates the significant role of the nervous system, particularly of its sympathetic autonomic part, in the process of ear active points appearance. The third experiment was not found to have a significant influence on the incidence of projection points of the compressed paw. The influence of the local blockage of a certain part of the hypothetical reflex arc between the compressed paw and a certain ear auricle point upon the results of the two preceeding experiments has thus been verified. The general pain threshold has not been significantly influenced by the applied dose of procaine.

The results of the presented work were found to corroborate the hypothesis on nervous system participation in the process of the ear active point appearance.
\end{abstract}

Dog, acupuncture, diagnosis, procaine blockage, reflex arc, autonomic nervous system.

In our previous work (Still and Konrád 1985) we concluded, basing on clinical experiments with dogs, that the induction of a painful process on the body periphery (paw compression by an elastic bandage) caused a manifestation of the corresponding electrically active and algetic points on the inner surface of the external auricle. This effect could be observed several minutes after applying the pressure.

The localization of these points was found to be identical in all positively reacting animals. Upon the application of the detection probe of the AKUDIAST I instrument a decrease of the electrical skin impedance at these points as compared to the condition prior to the experiment has been found. At the same time, a violent, sudden painful reaction of the dog has been observed in a statistically significant number of cases $(84 \%)$. 
These results are in accordance with the data published on the so called auriculodiagnosis as referred to in human literature data (König and Wancura 1975; Kropej 1977).

When explaining physiological manifestations of the therapeutical and diagnostic acupuncture two basic concepts are encountered: energistic, based on the old Chinese hypothesis about the energy cycle in the body and a more recent nervistic theory explaining this method on the reflex basis (Brunner 1980). Similar opinions concerning observations about the mechanism of the ear acupuncture effect have also been put forward (König 1975).

It is generally recognised that the phenomenon of ear acupuncture is mediated by the nervous action (Kropej 1977), auriculodiagnosis using probably the afferent stimulation transmitted from the site of peripheral irritation via part of the central nervous system to the corresponding projection area on the ear auricle surface. Stimulating (percutaneous stimulation, needle piercing, laser radiation, etc.) this point or zone the mentioned, pathologically injured body site or organ may be, on the other hand, often favourably affected. This is corroborated by a series of described sucessful therapeutical applications of this method, both in human (Ruizheng and Xide 1979 and others) and, sporadically, in veterinary medicine (Krüger and Krüger 1980).

Majority of works on human acupuncture (auriculoacupuncture) is concerned mostly with its therapeutical application, whereas in veterinary field the specialized literature is concerned with this topic only marginally, usually in a form of case histories or comparing the relation in man (Krüger and Krüger 1980; Noureau 1977; Brunner 1980; Wagner 1982).

In this contribution we have continued in our previous work on dogs order to verify the role of the nervous system, particularly of its autonomic part in the process of the ear point phenomenon appearance. The aim was to block out reversibly hypothetical afferent pathways between the site of peripheral stimulation and the ear auricle. Further, to eliminate the efferent sympathetic innervation of the chest limb and the ear auricle. Finally, we have attempted to eliminate non-specific effect of procaine on the general pain threshold applying this local anesthetic to the site unrelated to the thoracic limb and ganglion cervicothoracicum.

\section{Materials and Methods}

The experiment was carried out on five dogs of the Beagle breed (two males, three females) and on one cross-bred (male). The animals were clinically healthy. If the dog was used for repeated experiments, minimally 10 days break was allowed between the two subsequent experiments. The animals were not sedated by any medicament. For the detection of electrical and algetic changes on the dog ear auricle an AKUDIAST I instrument fitted with a nontraumatic spingmounted detection electrode was used, its detection area being $1 \mathrm{~mm}^{2}$ and detection pressure $785-1177 \mathrm{kPa}$ (i.e. $80-100 \mathrm{~g} / \mathrm{mm}^{2}$ ). The method of detection was the same as in our previous

Table 1

Manifestations of electrical and algetic changes in expected points of the paw on the dog ear auricles

\begin{tabular}{|l|c|c|c|}
\hline \multicolumn{1}{|c|}{ Experiment } & Number of dogs & $\begin{array}{c}\text { Decrease of electrical } \\
\text { skin impedance } \\
\text { (number of dogs) }\end{array}$ & $\begin{array}{c}\text { Detection } \\
\text { (Number of dogs) }\end{array}$ \\
\hline \begin{tabular}{l|c|c} 
Still and Konrád, \\
1985
\end{tabular} & 30 & 30 & 25 \\
1 & 5 & 0 & 0 \\
2 & 9 & 1 & 0 \\
3A & 5 & 5 & 2 \\
\hline 3B & 5 & 5 & 4 \\
\hline
\end{tabular}

Notes:

Still and Konrád (1985) - basic experiment when changes on ear auricles induced by peripheral stimulation (paw compression) were observed;

Experiment 1 - local procaine blockage of paw applied prior to the compression

Experiment 2 - efferent sympathetic blockage of paw of homolateral part of neck, head and including ext. auricle by procaine applied prior to the compression

Experiment $3 \mathrm{~A}$ - locally non-specific application of the same dose of procaine as in exp. 1 and $215 \mathrm{mi}$ nutes prior to the compression of the paw

Experiment 3B - locally non-specific application of higher procaine dose as compared to exp. 1 and 2 150 minutes and 15 minutes (the same dose) prior to the compression. 
Table 2

Statistical evaluation of the results from Table 1 with regard to the basic experiment - S̆till anł Konrád (1985), (denoted 0)

\begin{tabular}{|l|r|r|}
\hline \multirow{2}{*}{ Compared sets } & \multicolumn{2}{|c|}{ Statistical significance } \\
\cline { 2 - 3 } & Electrical skin impedance & Detection \\
\hline $0: 1$ & $\mathbf{P}<0.01$ & $\mathbf{P}<0.01$ \\
$0: 2$ & $\mathbf{P}<0.01$ & $\mathbf{P}<0.01$ \\
$0: 3 \mathrm{~A}$ & $\mathbf{P}>0.05$ & $\mathbf{P}>0.05$ \\
$0: 3 \mathrm{~B}$ & $\mathbf{P}>0.05$ & $\mathbf{P}<0.05$ \\
\hline
\end{tabular}

communication (Štill and Konrád 1985). The inner area of both ear auricles was thus measured, two times prior to the experiment and 2-3 times during the experiment.

In the experiment 1 the left metacarpus in its distal third had been infiltrated by $10 \mathrm{ml}$ of $2 \%$ procaine (Prokain inj. - Léčiva). After approximately 15 minutes, when no signs of superficial or deep sensitivity could be observed, the left paw was strongly compressed by an elastic bandage and the ear detection was then carried out.

In the experiment 2 , on five beagle dogs and on one cross-bred, the blockage of the ganglion cervicothoracicum has been effected using $4 \mathrm{ml}$ of $2 \%$ procaine, five times in the left and four times in the right side. The method described by Dietze et al. (1976) has been applied. Following the appearance of typical clinical signs of blockage (see previous citation) we commenced the compression of the corresponding autonomically blocked paw. The ear detection then followed.

Finally, in the experiment 3 we have applied the following doses subcutaneously on the chest wall (i.e. the area non-specifical to the experimental body part):

A) $4 \mathrm{ml}$ of $2 \%$ procaine 15 minutes prior to the paw compression to five dogs (four Beagles and one cross-bred),

B) $10 \mathrm{ml}$ of $2 \%$ procaine 150 minutes prior to the compression and $4 \mathrm{ml}$ of $2 \%$ procaine 15 minutes prior to the experiment to five dogs (four Beagles, one cross-bred).

\section{Results}

The obtained results are presented in Table 1 .

In the second experiment the nervi of plexus brachialis in two dogs were affected by procaine, this being manifested by shoulder limping.

The statistical evaluation of individual experiments with regard to the basic work (Štill and Konrád 1984) is presented in Table 2.

\section{Discussion}

Procaine induces a temporary depolarization of the nerve fibre, both somatic (motoric and sensitive) and autonomic. The basis of this disturbance is seen in the permeability change of the nerve membrane for sodium and potassium ions, the exchange of them being the precondition of the nerve impulse propagation (Melichar et al. 1972).

In our first experiment we have interrupted the impulse transmission through the somatic and autonomic nervous system upwards the limb, using the infiltration of the metacarpus. It follows from the table that the reflex manifestations did not appear at the ear auricle at the point of the ,paw”. In our previous work (Still and Konrád 1985) we have, however, found, under physiological conditions and at the same model situation, a decrease of the skin impedance in dogs in $100 \%$ and a positive finding of the painful point in $84 \%$ of cases. The comparison of these 


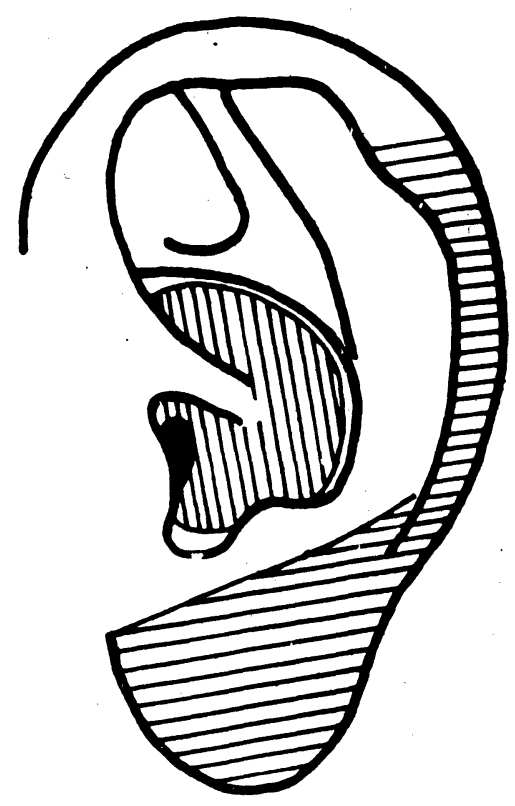

Fig. 1

Innervation diagram of man ear auricle

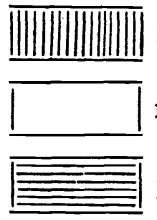

n. vagus

n. trigeminus

pl. cervicalis

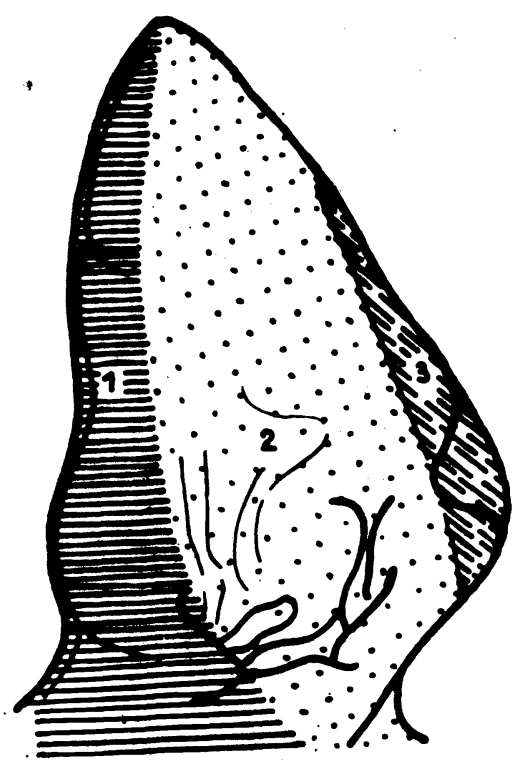

Fig. 2

Innervation diagram of dog ear auricle

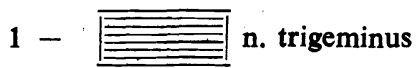

$2-\quad$ n. vagus

$\varepsilon-\quad$ $\quad$ pl. cervicalis

two experiments suggests the participation of the nervous system in manifestation of auriculodiagnosis, this being in agreement also with König (1975) and others

The localization of ear points corresponding to certain organs or body parts has been extensively discussed. Anatomical, embryological and clinical innervation schemes of the ear auricle of man (Kropej 1977) and dog (Noureau 1977) give us a basic conception for the elucidation of the localization of these points (Fig. 1). The significance of autonomic - particularly sympathetic - nervous system in ear acupuncture has been generally emphasized (König 1975). In order to verify this assumption we have carried out the second experiment - the influence of autonomic blockage of the damaged peripheral area and of the ear auricle on the functional manifestation of auricular active points. Ganglion cervicothoracicum sends, according to current anatomical conception ( $\mathrm{Najbrt}$ et al. 1982), largely postganglionic sympathetic fibres that reach the chest limb together with spinal nerves and in the form of perivascular plexuses. These plexuses are responsible for skin vasoconstriction in sympathicotonia. Autonomic, and hence sympathetic nerve sensitive impulses originate in angioreceptors in the chest limb, reacting to mechanical and temperature impulses and to chemical blood composition. When injection of procaine is applied to the ganglion cervicothoracicum the blockage of efferent part of the sympatheticus 
appears (as far as the chest limb is concerned) which is manifested by vasodilatation. Similar manifestation is observed at the corresponding half of the neck, head and ear auricle.

During the whole experiment the proprioception of the paw outlasted, the exceptions being the two dogs with shoulder limp. Although we have not managed (in

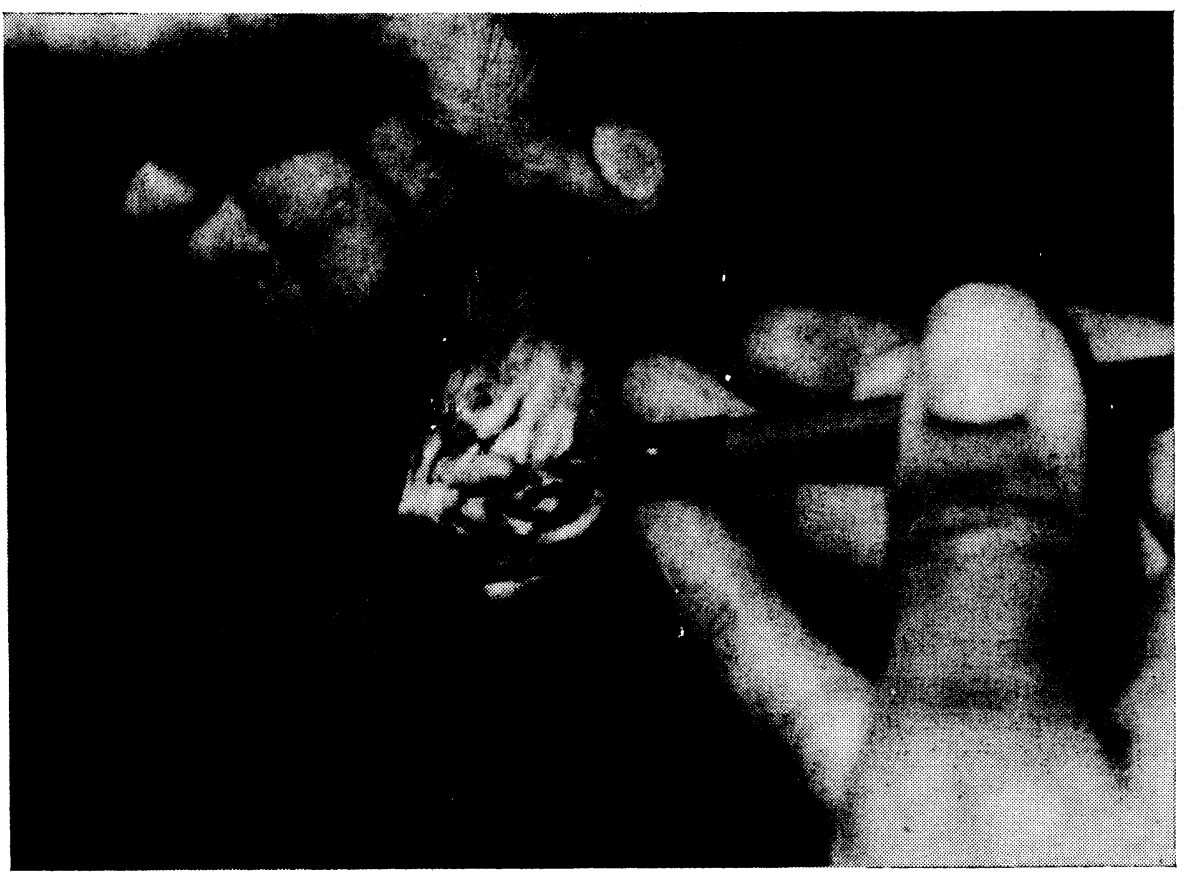

Fig. 3

Detection of active ear points

7 out of 9 dogs) to affect the sensitive neuron, hypothetically responsible for the impulse propagation from the compressed paw to the projection ear area, this zone nevertheless manifested itself only once electrically and never as detection sensitive (Table 1). We thus suppose that, when sympathetic efference of the chest limb is blocked, the angioreceptors of the compressed paw do not react enough to be able to induce the manifestation of the mentioned changes in the ear auricle. The negative auriculodiagnostic finding has been observed on both ear auricles. At the same time the sympathicus on the corresponding half of neck, head and ear auricle has been , blocked, which could influence the point of projection as well. These findings will undoubtedly require further experimental work and specification.

Unfortunately the extensive connection of the autonomic part with the somatic nervous system makes impossible to carry out the isolated blockage.

The results of our third experiment (3A) corroborate that the negative findings of detection sensitive points on the ear, if the ganglion cervicothoracicum is blocked, are not associated with a total increase of general pain threshold in animals due to procaine application. It follows from the results of the experiment $3 \mathrm{~B}$ that if the higher dose of procaine was administered in a longer lapse of time prior to the 


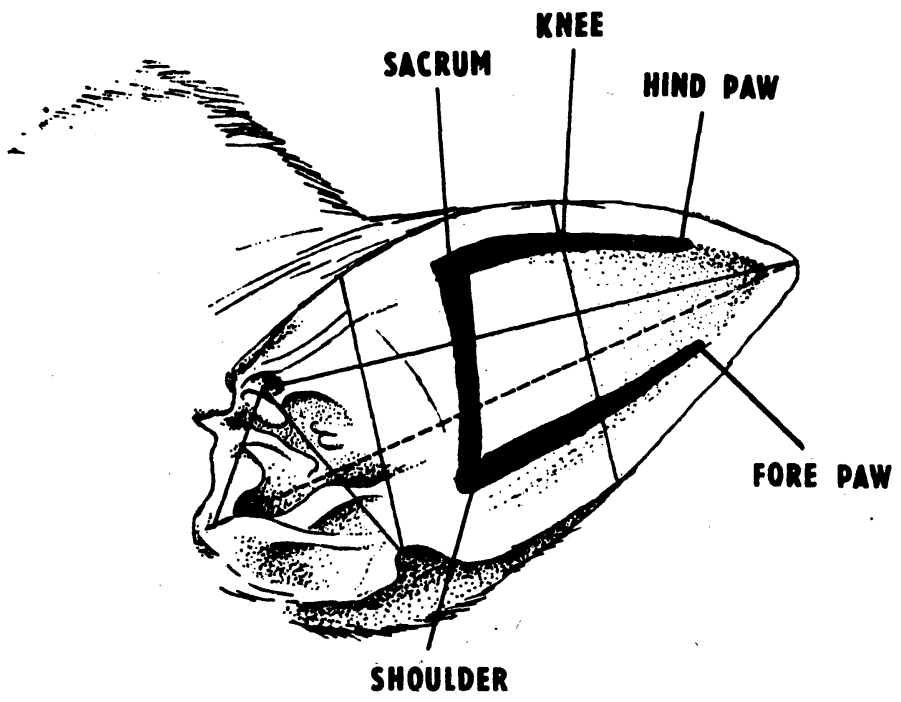

Fig. 4

Projection zones of the spine, fore and hind limbs on ear auricle of the dog

experiment, the manifestation of the active ear points has been negatively affected. The results of our experiments favour the fact that the decrease of skin impedance in the active point serves as a more reliable indicator than the appearance of detection painfullness. We are, however, aware that particularly in repeated detections, erro-

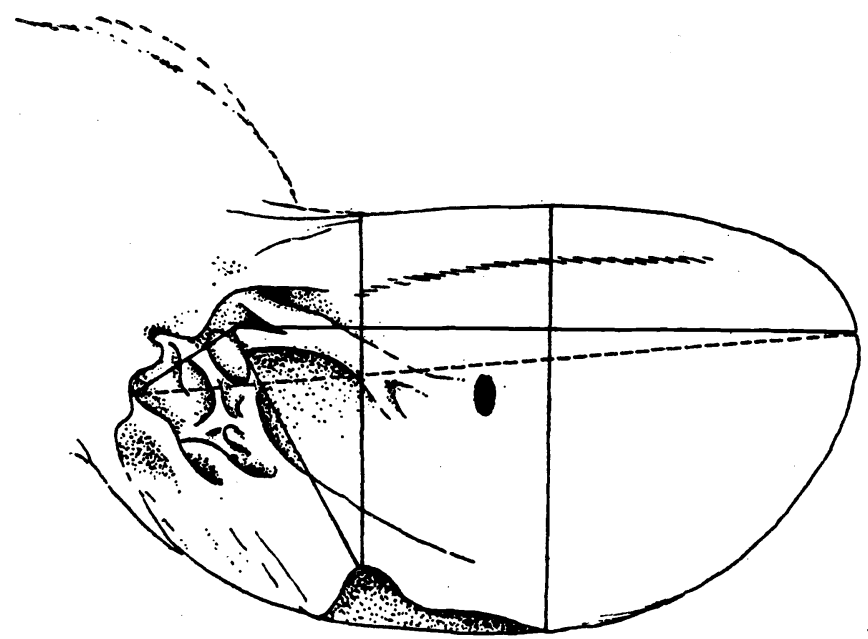

Fig. 5

Zone of detected strong painful reaction on both ear auricles corresponding to clinically verified lumbalgia (x-ray examination negative) in a dachshund male, age 8.5 year 


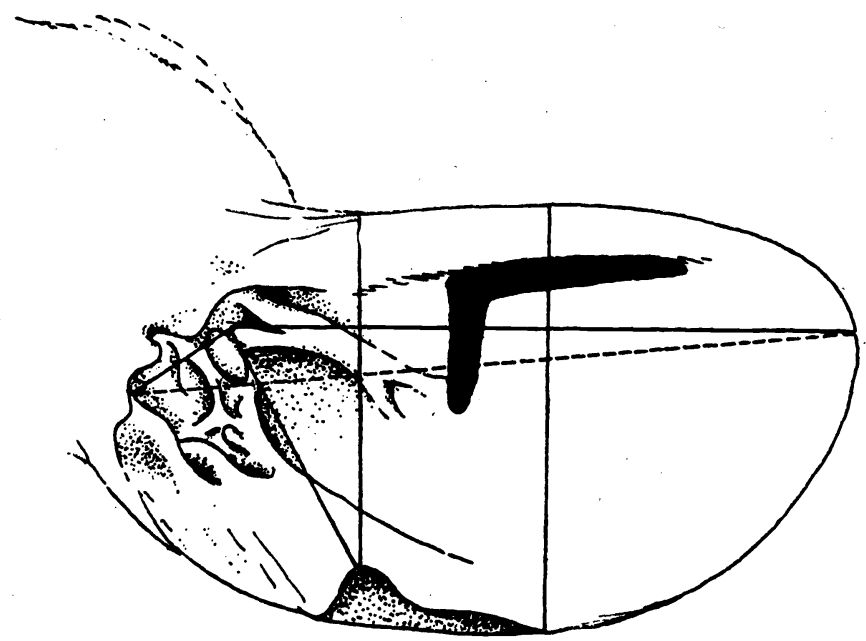

Fig. 6

Auriculo-diagnostic finding of strong painful reaction and decreased skin impedance with total spine paresis (thoracolumbal discopathy of the 4th degree). At accidental examination of the ear auricles three days before the onset of paresis, when the dog showed only slight symptoms of hind limb ataxia, no painful reactions were detected. After recovery the points were no more present.

neous results can be obtained (Hálek, Kolářová, Opavský 1982). We thus believe that it is necessary to evaluate both electrical and algetic changes in the active ear points, even though the technical errors of these skin electrical measurements are minimal.

Statistically significant difference $(\mathrm{P}<0.01)$ between the incidence of ele ctrically active and algetic points on the ear auricle, when model stimulation of the paw was used (Still and Konrád 1985) and the incidence of these points in a similar experiment carried out after the local anaesthesia (experiment 1) or after the blockage of efferent autonomic innervation for the given area (experiment 2) has been found using the Chi quadrate. On the other hand, the in fluence of non-specific application of local procaine anesthetic prior to the experiment on the manifestation of active ear points was not found to be of statistical significance.

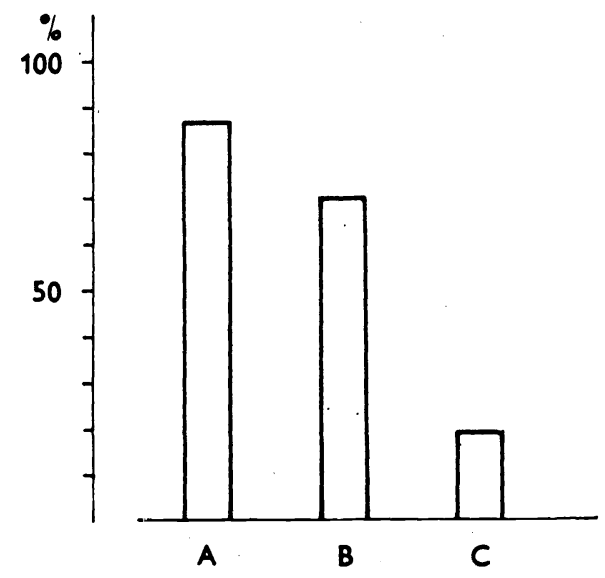

Fig. 7

Dependence of successful auriculodiagnosis ( $Y$ axis) (ordinate) on the type of the disease. Abscissa - A acute inflammatory processes, B - chronic inflammatory processes, C - degenerative changes 
Segmental and local specifity of the autonomic nervous system projection has not been so far studied in detail. As reported by e.g. Randal (1977) who examined the autonomic heart innervation, these principles are partially valid even here and the effect of autonomic nerve system is not necessarily only diffuse but also locally specific, differentiated. This can be significant also in the case of auriculodiagnosis and auriculotherapy, the hypothetical reflex arc being certainly polysynaptic, functioning via the participation of neurons of various segments of the central nervous system.

Since the experiments were conducted on animals the influence of suggestion, autosuggestion, hypnosis and psychosis can be excluded, contrary to the critical assessment of the effect of acupuncture in man (Prok op 1984). The obtained findings suggest the objective existence of the phenomenon of active ear points in the dog. We have also succeeded to demonstrate the decisive role of the nervous system, particularly of its sympathetic system, in auriculodiagnosis, which is in agreement with a generally accepted nervistic reflex conception of acupuncture (König 1975).

We have been unable to compare our results with another similar papers so we can regard our study as a starting work that should be followed by further specifying studies.

\section{Úloha nervového systému ve výskytu ušních bodů pro akupunkturu u psů}

$\mathrm{Na}$ šesti psech ( 5 beagle a 1 křiženec; 3 psi, 3 feny) jsem provedl tři experimenty: 1. Navodil jsem prokainovou blokádu prední tlapky a poté jsem silně stáhl tuto tlapku. 2. Provedl jsem prokainovou blokádu ganglion cervicothoracicum, které zásobuje sympatickou inervací přední končetinu, krk, hlavu i ušní boltec téže strany, a poté jsem komprimoval silně př́slušnou tlapku. 3. Provedl jsem nespecifickou aplikaci prokainu $\mathrm{v}$ množství jako $\mathrm{v}$ předchozích pokusech nespecificky do podkoží hrudníku. Následně $v$ patřičném časovém odstupu jako $v$ předchozích pokusech jsem provedl silnou kompresi tlapky. Kompresi tlapky pružným obinadlem jsem prováděl vždy po dobu 30 minut, střídavě na obou hrudních končetinách. Elektrické a algické detekční změny na obou ušních boltcích jsem sledoval před pokusem, během něj i krátce po sejmutí obinadla.

$\mathrm{V}$ prvním i druhém pokusu nedošlo $\mathrm{k}$ výskytu bolestivých bodů na ušních boltcích, jen ojediněle jsem detekoval snižení kožního odporu v předpokládaném bodu korespondujícím s přední tlapkou. Tento statisticky vysoce významný rozdíl $(P<0,01)$ v nálezu oproti citovanému obdobnému pokusu bez specifického ovlivnění lokálním anestetikem svědčí pro důležitou roli nervového systému, zvláště jeho sympatické autonomní složky v procesu vzniku ušních aktivních bodů. Třetí pokus neovlivnil podstatně výskyt projekčních bodů tlapky po její kompresi. Tím jsem si zpětně oveřil, že výsledky předchozích dvou pokusů byly ovlivněny právě místním vyblokováním uř̌itého úseku hypotetického reflexního oblouku mezi komprimovanou tlapkou a určitým bodem ušního boltce. Celkový práh bolestivosti nebyl podstatně ovlivněn aplikovanou dávkou prokainu.

Výsledky předložené práce podporují hypotézu o reflexní podstatě ušní akupunktury.

\section{К вопросу нейрального механизма воздействия ушной иглотерапии у собак}

У шести ообак (бигль и помесь, 3 пса, 3 суки) проводили три эксперимента: 1. перед тем, как вызвать боль на лапе проводили ее блокаду 
прокаином. 2. перед сжатием лапы провели прокаиновую блокаду ganglion cervicothoracicum, снабжающепо симпатической инервацией переднюю конечность и ушную раковину. 3. перед компрессией лапы вводили прокаин подкожно на грудной клетке.

Компрессию лапы проводили почередно на обеих грудные конечностях.

В ходе первого и второто экспериментов не наблюдались болезненные реакции в области лапы, лишь в отдельных случаях были установлены точечные понижения сопротивляемости кожи. Данная статистически важная разность по сравнению с экспериментом без использования нестного обезболивания (Štill и Konrád 1984) свидетельствует о важной роли нервной системы, особенно епо симпатической части, в процессе возникновения активных точек ушной раковины.

Третий эксперимент с местным неспецифическим применением анестетиков не оказал существенного влияния на наличие проекционных точек лапы. Тем самым, было проверено, что результаты предыдущих двух экспериментов находились под влиянием именно местной блокировки части гипотетической рефлекторной дуги между сжатой лапой и определенной точкой ушной раковины. Следовательно, порго болезненности не находился под существенным влиянием вводимой дозы прокаина.

Результаты работы свидетельствуют о рефлекторной сущности ушного итлоукалывания и объективном существовании феномена активных точек уха.

\section{References}

BRUNNER, F.: Akupunktur für Tierärzte - Akupunktur der Kleintiere. 1st Ed. Biologisch Medizinische Verlagsgesellschaft, Schorndorf, 1980, p. 56.

DIETZE, O. - SCHAETZ, F. - SLEITER, H. - TEUSCHER, R.: Anästhesie und Operationen bei Gross- und Kleintiere. 1st Ed. Hirzel Verlag, Leipzig, 1975, pp. 195-189.

HÁLEK, J. - KOLÁŘ́OVÁ, J. - OPAVSKYY, J.: Problematika měření odporu v aktivních bodech kůže. Fysiatrický věstník, 60, 1982; 258-266.

KÖNIG, G.: Theoretische Grundlage der Ohrakupunktur. Akupunktur - Theorie und Praxis, 3, $1975 ; 180-184$.

KÖNIG, G. - WANCURA, I.: Einführung in die chinesische Ohrakupunktur. 6th Ed. Karl F. Haug, Heidelberg, 1975, pp. 226-229.

KROPEJ, H.: Systematik der Ohrakupunktur. 3rd Ed. Karl F. Haug, Heidelberg, 1977, pp. $213-216$.

KRÜGER, H. - KRÜGER, P.: Ohrakupunktur bei Bewegungsstörungen der Kleintiere. Prakt. Tierarzt, 61, 1980; 119-129.

MELICHAR, B. - ČLADNÍ, M. - KŇAŽKO, L. - NOVÁČEK, L. - PALÁT, K. SOVA, J.: Chemická léciva. 1st Ed. Avicenum, Praha, 1972, 895 p.

NAJBRT, R. - BEDNÁR̆, K. - ČERVENÝ, Č. - KAMAN, J. - MIKYSKA, E. - ŠTARHA, O.: Veterinární anatomie. 1st Ed. SZN, Praha, Vol. 2, pp. 443-464.

NOUREAU, J. P. R.: Introduction a l'acupuncture auriculaire canine. (Thése pour le doctorat). Ecole Nationale de Toulouse, No 131, 1977, pp. 21-45.

PROKOP, O. - DIETZ, G. - HETCH, A. - HOFFMANN, C. - JENTZSCH, G. - KERDEOVA, C. - KOCH, T. - REIMANN, W. - SCHIRMER, S. - SEIDEL, K. - STELZER, E.: Lékařské vědy proti pověrám a šarlatánství. 4th Ed. (1st Czech) Avicenum, Praha, 1984, $311 \mathrm{p}$.

RANDAL, W. C.: Neural regulation of the heart. 1st Ed. Oxford Univ. Press, New York, 1977.

RUIZHENG, X. - XIDE, H.: A study of auricular acupuncture. In: Advances in acupuncture and acupuncture anaesthesia, 1st Ed. Tiantan Xili, Beijing, 1979; 120-121.

STILL, J. - KONRÁD, J.: Experimental verification of auriculodiagnosis in the dog. Acta vet. Brno, 54, 1985, in press. 
WAGNER, R. W.: Comparative somatotrophy and reference acupuncture point therapy in canine and feline auricular medicine (outline). In: Proceeding of the eight annual International Veterinary Acupuncture Conference, Fort Mitchell, Kentucky, 1982; 137-145. 